\title{
脳虚血後の脳機能，脳代謝おょび脳組織変化に 対する血糖値の影響
}

間部 英雄 梅村 訓吉田毅永井肇

要旨：脳虚血時における血糖値が血流再開後の脳機能, 脳エネルギー代謝および病理組織学 的変化, 更には膜リン脂質の崩壊に及ぼす影響について検討した。ラットで4-vessel occlusion に mild な低血圧を加えることにより，30分間の両側大脳半球の虚血を作製したのち，120分間 の血流再開を行なった。虚血開始前の血糖値により, group 1 (平均 $149 \mathrm{mg} / \mathrm{d} l$ ), group 2 (平 均 $373 \mathrm{mg} / \mathrm{d} l$ ), group 3 (平均 $788 \mathrm{mg} / \mathrm{d} l$ ) の 3 群に分けた。虚血中は 3 群共脳波は isoelectric であった. group 1 では血流再開後平均 24 分で, group 2 では平均 52 分で脳波が再出現し始めた が, group 3 ではほとんど再出現しなかった。高血糖群では, 血流再開120分後の虚血性組織変 化が著明であった。血流再開120分後の ATP 含量は, 高血糖群では, 正常血糖群に較べて低値 を示した。脳虚血時の遊離脂肪酸の増加は 3 群間に差を認めなかった。脳虚血中の血糖值が血 流再開後の脳組織傷害と密接に関連していることが示唆された.

Key words : experimental cerebral ischemia, lactic acidosis, EEG, brain energy metabolism, free fatty acids

(脳卒中 $7: 336-343,1985$ )

脳虚血時には, 嫌気性解糖が亢進し, 脳組織内に乳 酸が蓄積し, lactacidosis が生ずる1)。この acidosis が 組織の autolysis を促進することが, 脳虚血時の脳組 織傷害の一因と考兄られてきた ${ }^{2) 3}$ ，完全脳虚血あるい は高度の不完全脳虚血では, 乳酸蓄積の程度は, 脳虚 血時の血糖值に影響される ${ }^{4) 5}$. 虚血により, 生体膜を 構成するリン脂質が崩壊し, 脳組織内に遊離脂肪酸が 増加し ${ }^{6)}$, この遊離脂肪酸拉よびその代謝物も又組織 傷害を起すという考光もある7).一方りン脂質を加水 分解し, 遊離脂肪酸を生ずる phospholipase $\mathrm{A}_{2}$ の至適 $\mathrm{pH}$ は5.5であるので8), lactacidosis が強い場合には, phospholipase $\mathrm{A}_{2}$ 活性が方進している可能性もある.

著者らは, 脳虚血時の血糖值が血流再開後の脳機能, 脳エネルギー代謝打よび病理組織学的変化, 更には虚 血時の遊離脂肪酸の増加に及ぼす影響について検討し たので報告する。

\section{実験方法}

実験動物として体重300-400g の雄のウイスター系

名古屋市立大学医学部脳神経外科学教室
ラット 46 匹を用い，チオペンタールナトリウム $40 \mathrm{mg} /$ $\mathrm{kg}$ 腹腔内投与により麻酔を行ない, 第 1 頝椎の alar foramen を通じて, 両側椎骨動脈を電気凝固により閉 塞したのち，気管切開を行ない，塩化アルクロニウム $0.6 \sim 0.8 \mathrm{mg} / \mathrm{kg}$ 静脈内投与により非動化し, 調節呼吸 とし，笑気と酸素で麻酔を維持した。両側大腿動脈㧤 よび一側大腿静脈にポリェチレンチューブを插入し， これょり血圧の測定，血液ガス測定のための採血ある いは低血圧のための脱血,さらに薬剤拈よび血液の注 入を行なった。

脳虚血の作製は, 前述の両側椎骨動脈閉塞に加えて, 両側総䅡動脈を Mayfield の動脈瘤クリップでクリッ プし，更に脱血により収縮期血圧を $100 \mathrm{mmHg}$ にする ことにより両側大脳半球の虚血を作製した．30分間の 脳虚血後に, 両側総䅡動脈にかけたクリップを解除し, 脱血時に採取した血液を注入し，全身血圧を虚血前の 値に戻すことにより血流再開を行なった。

脳機能の指標として脳波を用いた。両側頭頂部で左 右対称に径 $1.7 \mathrm{~mm}$ の金属ネジを頭蓋骨に固定し, 鼻根 部の骨に固定した金属ネジを不関電極として, 硬膜上 から単極誘導により脳波を記録した。 
血流再開 120 分後にラットを屠殺して, 脳を取り出 し，10\%中性ホルマリン液で固定し, hematoxylineosin 染色およびluxol fast blue 染色を行ない, 光顕 レベルで病理組織学的変化を観察した。

虚血前, 虚血中掞よび血流再開後の各時点で, 頭蓋 骨上に装着したプラスチック製漏斗に液体窒素を注入 して, in situ の状態で頭部を凍結したのち ${ }^{9)}$, 液体窒素 を注ぎながら，脳を剔出し， $-80^{\circ} \mathrm{C} て ゙$ 涷結保存した。凍 結脳を秤量 $(150-300 \mathrm{mg})$ し, 液体窒素中で粉砕した ものを各測定の試料とした。遊離脂肪酸の測定は，液 体窒素中で粉砕した脳組織に $0.1 \mathrm{~N} \mathrm{HCl} 2 \mathrm{~m} l$ と dieth$\mathrm{yl}$ ether $5 \mathrm{~m} l$ を加兄, 20 分間擋挥したのち, $3000 \mathrm{rpm}$ で10分間遠心し，上清のェーテル相に脂肪酸を抽出分 離し, 蒸発乾固したのち, P-bromophenacyl bromide および triethylamine を加光, $50^{\circ} \mathrm{C} て ゙ 2$ 時間反応させ, 脂肪酸の P-bromophenacyl esterを高速液体クロマ トグラフィー（Shimadzu, LC-5A）で測定した。ATP の測定は, 液体窒素中で粉砕した脳組織に IN 過塩素 酸を加光混合し, $0.5 \mathrm{M}$ 炭酸カリウムで中和したのち, $12,000 \mathrm{rpm}$ で10分間遠心し，その上清液を高速液体ク ロマトグラフィーで測定した。

虚血直前の血糖值により, 動物を次の 3 群に分けた。 group 1 : 正常血糖群 (血糖值116-196mg/d $l$, mean \pm $\mathrm{SE} 149 \pm 12 \mathrm{mg} / \mathrm{d} l$ ), group $2:$ 中等度高血糖群（血糖 值 $316-430 \mathrm{mg} / \mathrm{d} l$, mean $\pm \mathrm{SE} 373 \pm 16 \mathrm{mg} / \mathrm{d} l$ )一虚血 前に $50 \%$ ブドゥ糖液 $0.5 \mathrm{~m} l$ を静注したもの, group 3 : 高度高血糖群 (血糖值 $684-954 \mathrm{mg} / \mathrm{d} l$, mean $\pm \mathrm{SE}$ $788 \pm 52 \mathrm{mg} / \mathrm{d} l$ ) 一虚血前に $50 \%$ ブドウ糖液 $2 \mathrm{~m} l$ を静

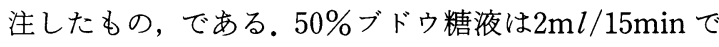
緩徐に静注し, 投与終了後 $5 \sim 10$ 分で虚血を開始した。

\section{結 果}

Table 1 に各群の虚血前（group 2 および 3 はブド ウ糖負荷後)拉よび血流再開60分および120分後の動脈 血 $\mathrm{pH}, \mathrm{PCO}_{2}$ および $\mathrm{PO}_{2}$ ならびに平均動脈血圧 (MABP) を示した。

Fig. 1 亿虚血前, 虚血中および血流再開後の各群 の血糖值の変動を示した.

両側椎骨動脈を閉塞したのち，両側総䅡動脈をク リップし，更に収縮期血圧を $100 \mathrm{mmHg}$ とすると，全例 脳波は平坦となり，30分間の虚血中 isoelectric のまま であった. 30 分間の虚血後血流再開を行ならと, group 1 では17-35分 (平均24分) で脳波が出現し始め, 次第 に回復したが虚血前までには回復しなかった. group 2 では40一63分（平均52分）で脳波の再出現をみたが， group 1 に比較すると回復は悪かった. group 3 では血 流再開120分後までほとんど isoelectric のままであっ たが，血流再開80-110分で脳波が再出現し，平坦化脳 波の間に burst が出現する burst suppressionの像を 示すものもみられた（Fig. 2).

病理組織学的検索を行なうと, group 1 の血流再開 120 分後の頭頂部皮質の病理組織像では, 神経細胞の軽 度の萎縮，濃染などが認められた(Fig. 3A). group 3 の血流再開120分後の病理組織像では, 大脳半球全般に 浮腫が著明で，神経細胞はクロマチンに濃染され，変 形をきたし，壊死に陥っている細胞もみられ，虚血性

Table 1 Physiological parameters in each experimental groups subjected to 30 minutes of incomplete cerebral ischemia followed by 120 minutes of recirculation

\begin{tabular}{|c|c|c|c|c|c|}
\hline $\begin{array}{c}\text { Experimental } \\
\text { Group }\end{array}$ & & $\begin{array}{c}\mathrm{MABP} \\
(\mathrm{mmHg})\end{array}$ & $\underset{(\mathrm{mmHg})}{\mathrm{PaCO}_{2}}$ & $\begin{array}{c}\mathrm{PaO}_{2} \\
(\mathrm{mmHg})\end{array}$ & $\mathrm{pH}$ \\
\hline \multirow[t]{3}{*}{ Preischemia } & $1(n=6)$ & $138 \pm 9$ & $36.0 \pm 1.9$ & $187.8 \pm 18.7$ & $7.38 \pm 0.03$ \\
\hline & $2(n=6)$ & $150 \pm 5$ & $35.3 \pm 1.5$ & $162.6 \pm 11.5$ & $7.39 \pm 0.01$ \\
\hline & $3(n=7)$ & $145 \pm 7$ & $35.4 \pm 0.9$ & $174.6 \pm 11.0$ & $7.42 \pm 0.01$ \\
\hline Recirculation & $1(n=6)$ & $137 \pm 9$ & $31.4 \pm 2.5$ & $172.7 \pm 10.3$ & $7.36 \pm 0.03$ \\
\hline \multirow[t]{2}{*}{$60 \mathrm{~min}$} & $2(n=6)$ & $139 \pm 3$ & $31.3 \pm 2.2$ & $160.9 \pm 22.5$ & $7.33 \pm 0.03$ \\
\hline & $3(n=7)$ & $139 \pm 5$ & $38.7 \pm 0.7$ & $163.6 \pm 13.2$ & $7.32 \pm 0.03$ \\
\hline Recirculation & $1(n=6)$ & $133 \pm 8$ & $34.9 \pm 1.4$ & $166.1 \pm 15.9$ & $7.35 \pm 0.02$ \\
\hline \multirow[t]{2}{*}{$120 \mathrm{~min}$} & $2(n=5)$ & $136 \pm 4$ & $36.1 \pm 3.9$ & $169.1 \pm 9.5$ & $7.36 \pm 0.01$ \\
\hline & $3(n=6)$ & $135 \pm 6$ & $36.3 \pm 1.7$ & $164.2 \pm 14.4$ & $7.34 \pm 0.02$ \\
\hline
\end{tabular}

Experimental groups : group 1, normoglycemia ; group 2, infused with a $50 \%$ glucose solu$\operatorname{tion}(0.5 \mathrm{~m} l)$ before ischemia; group 3, infused with a $50 \%$ glucose solution $(2 \mathrm{~m} l)$ before ischemia

The values are means $\pm \mathrm{SE}$ 


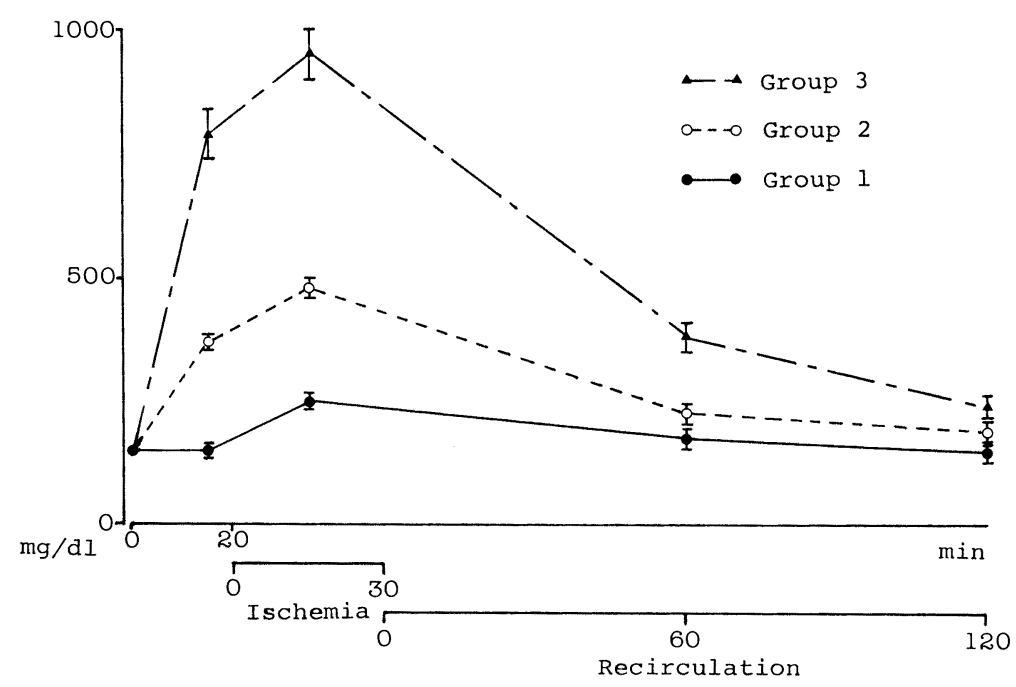

Fig. 1 Blood glucose concentrations in rats subjected to incomplete cerebral ischemia followed by recirculation.

Group 1: normoglycemia, Group 2: infused with a $50 \%$ glucose solution $(0.5$ $\mathrm{m} l$ ) before ischemia, Group 3: infused with a $50 \%$ glucose solution $(2 \mathrm{~m} l)$ before ischemia.

Means \pm SE.

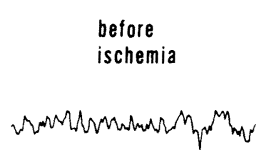

during

ischemia
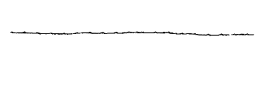

30 min after

recirculation

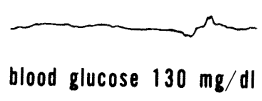

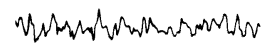

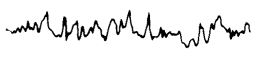

$1 \mathrm{sec}$
$60 \mathrm{~min}$ after recirculation

120 min after recirculation.
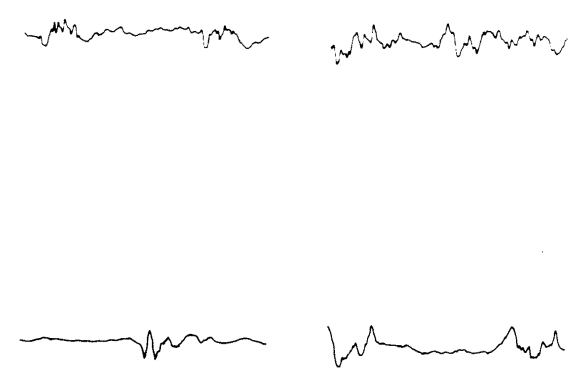

$N N M$

Fig. 2 EEG activity before, during and after 30 minutes of severe incomplete cerebral ischemia. The upper, middle and lower show EEG of group 1, 2 and 3, respectively. 
変化が強く認められた（Fig. 3B）.

脳組織の ATP 含量は, 虚血30分の時点では, group

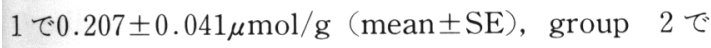
$0.184 \pm 0.007 \mu \mathrm{mol} / \mathrm{g}$, group 3 で $0.143 \pm 0.013 \mu \mathrm{mol} /$ $\mathrm{g}$ と著明な減少を示したが, 各群間に推計学的に有意

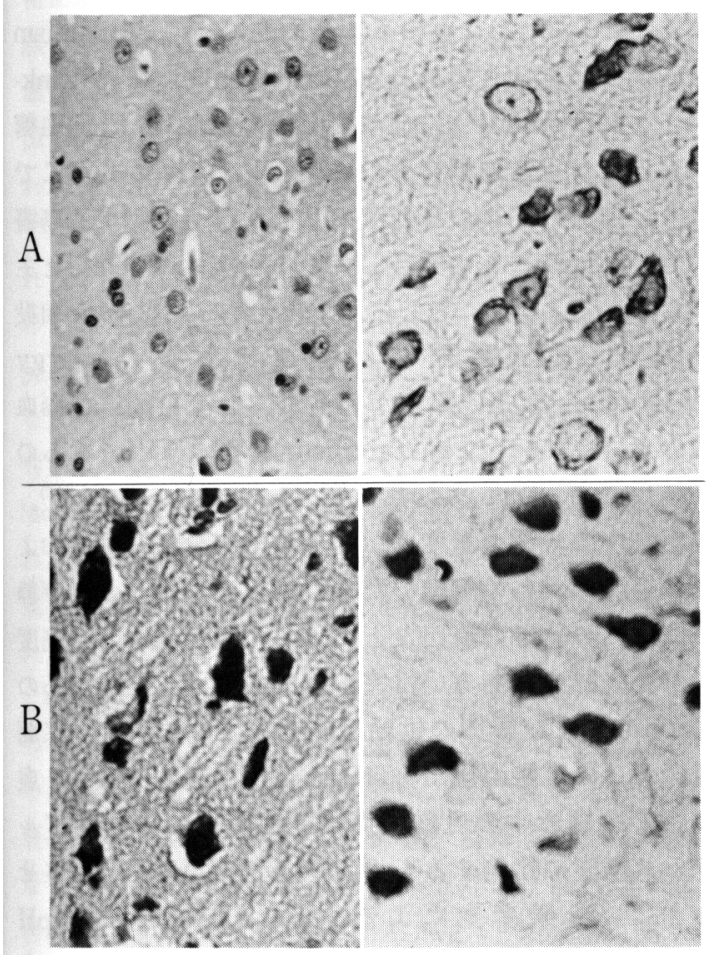

Fig. 3 Histological findings of cerebral cortex after the end of 120 minutes of recirculation period.

A : normoglycemic rat, B: hyperglycemic rat. Left of both pictures show hematoxylin-eosin stain and right luxol fast blue stain. Remarkable shrinkage and hyperchromasia and perineural edema are noted in Fig. 3B. A Left, $\times 300$. A Right \& B, $\times 600$.
差はみられなかった. 血流再開120分後では group 1 は $2.195 \pm 0.062 \mu \mathrm{mol} / \mathrm{g}$, group 2 では $1.877 \pm 0.016$ $\mu \mathrm{mol} / \mathrm{g}$, group 3 では $1.501 \pm 0.080 \mu \mathrm{mol} / \mathrm{g}$ であった (Table 2).

虚血30分の時点での脳組織中の遊離脂肪酸は, パル ミチン酸, ステアリン酸, オレイン酸, アラキドン酸 の 4 種の脂肪酸の合計は, group 1 では198.2土14.1

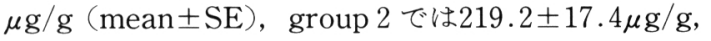
group 3 では218.3土22.1 $\mu \mathrm{g} / \mathrm{g}$ と虚血前值の約 3 倍の 増加を示したが， 3 群間に有意差は認められなかった。 個々の脂肪酸についても各群間に有意差は認められな かった (Table 3).

\section{考按}

実験的脳虚血の作製方法として，これまでに数多く の方法が報告されている. ラット等の小動物では, 頭 蓋内圧亢進による完全脳虚血 ${ }^{10)}$, 頚部を cuff で圧迫し 血圧を下げる方法 ${ }^{11)}$, microembolism 法 $^{12)}$, 両側総頝 動脈の閉塞に低血圧を加味する方法 ${ }^{13}$, 一側総頝動脈 の閉塞に hypoxia を加学る方法 ${ }^{14)}$, 中大脳動脈の閉 塞 $^{15)}$, あるいは mongolian gerbil での一側総頚動脈の

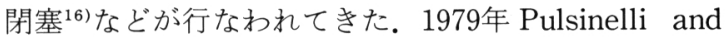
Brierley ${ }^{17)}$ がラットに招ける4-vessel occlusionによ

Table 2 Brain concentrations $(\mu \mathrm{mol} / \mathrm{g})$ of ATP. Preischemic control values(after occlusion of bilateral vertebral arteries) are $2.868 \pm 0.125$ $\mu \mathrm{mo} l / \mathrm{g}($ mean $\pm \mathrm{SE})$. Values are mean $\pm \mathrm{SE}$.

\begin{tabular}{c|c|c}
\hline $\begin{array}{c}\text { Experimental } \\
\text { group }\end{array}$ & $\begin{array}{c}\text { Ischemia } \\
\text { 30min }\end{array}$ & $\begin{array}{c}\text { Recirculation } \\
120 \mathrm{~min}\end{array}$ \\
\hline 1 & $0.207 \pm 0.041$ & $2.195 \pm 0.062$ \\
2 & $0.184 \pm 0.007$ & $1.877 \pm 0.016^{*}$ \\
3 & $0.142 \pm 0.013$ & $1.501 \pm 0.080^{* *}$ \\
\hline
\end{tabular}

$*: \mathrm{p}<0.05$, group 1 versus group 2 .

**: $\mathrm{p}<0.01$, group 1 versus group 3 .

Table 3 Concentrations $(\mu \mathrm{g} / \mathrm{g})$ of free fatty acids in the brain tissue after 30 minutes of ischemia

\begin{tabular}{|c|c|c|c|c|}
\hline $\begin{array}{l}\text { Experimental } \\
\text { group }\end{array}$ & Total FFA & $\begin{array}{l}\text { Palmitic acid } \\
+ \text { Oleic acid }\end{array}$ & Stearic acid & $\begin{array}{l}\text { Arachidonic } \\
\text { acid }\end{array}$ \\
\hline Before ischemia & $67.7 \pm 7.4$ & $38.6 \pm 3.7$ & $21.4 \pm 3.6$ & $7.7 \pm 1.1$ \\
\hline $\begin{array}{ll}\text { Ischemia } & \text { group } 1 \\
\text { 30min } & \end{array}$ & $198.2 \pm 14.1$ & $93.2 \pm 6.2$ & $59.4 \pm 8.4$ & $45.6 \pm 7.9$ \\
\hline group 2 & $219.2 \pm 17.4$ & $102.3 \pm 2.4$ & $69.6 \pm 14.9$ & $47.3 \pm 1.2$ \\
\hline group 3 & $218.3 \pm 22.1$ & $95.9 \pm 8.5$ & $67.4 \pm 8.4$ & $55.0 \pm 6.7$ \\
\hline
\end{tabular}

Values are mean \pm SE. FFA : free fatty acid. 
る両側大脳半球の虚血モデルを発表して以来, この 4vessel occlusion モデルが脳虚血の実験的研究に広く 使用されつつある. Pulsinelli and Brierley ${ }^{17)}$ はこのモ デルでは，ある strainでは無麻酔で 4-vessel occlusionを行ならと77\%が unresponsive となり righting reflex が消失し，脳波は isoelectric となったが， strain によっては unresponsive となる率がもっと低 率であると述べている。このようにこのモデルでは, 4-vessel occlusion による脳血流の低下はかなりバラ ツキがある。著者らが麻酔下に4-vessel occlusionを 行なったところ, 正常血圧下 (平均動脈圧 $140 \mathrm{mmHg}$ 前 後)では, 脳波が isoelectric となったのは35例中17例, 49\%であったので，より再現性の良好な虚血モデルと するため, 収縮期血圧を $100 \mathrm{mmHg}$ とやや低血圧とし た.このように 4-vessel occlusion に mildな低血圧を 加觉ることにより，全例で脳波はisoelectricとなっ た.脳波が平坦となるのは脳血流量が正常の $80 \%$ 以下 となる場合であるので1819), 著者らの用いた虚血モデ ルは脳血流量が正常の $80 \%$ 以下と高度の両側大脳半球 の虚血モデルであり，かつ再現性が高いといえる.

1961年 Friede and van Houten ${ }^{2}$ はラットの小脳組 織をグルコースを含んだ medium 中で incubate した ところ, $\mathrm{pH}$ の低下に伴って, 病理組織変化を生じ, こ の組織変化と $\mathrm{pH}$ の低下はglycolysis blockする ことにより抑制されることを観察した。このことから， この組織変化は嫌気性解糖により生じた酸性代謝物に 基因することが示唆された。1977年, Myers and Yamaguchi ${ }^{20)}$ は猿で14分間の心停止を起させた際に， 心停止を起す直前に $5 \%$ グルコースを投与した動物で は，生食水を投与した動物に較べて，血流再開後の神 経学的回復が悪く, 病理組織学的変化も強いことを観 察し, 虚血時の高血糖が虚血に対する脳の反応に悪影 響を及ぼすことを示唆した。 その後, 脳虚血時の高血 糖は正常血糖よりも, 血流再開後の神経学的欠落症状 が強く ${ }^{11)}$, 病理組織学的により強い傷害が認めら $れ^{5) 211}$, energy metabolite $e^{422)}$ 扣よび電気生理学的 な4223)回復が悪いことが示された。

脳虚血時の高血糖は, 血流再開後の脳機能, 脳代謝 の回復, 更には病理組織学的変化に悪影響を及ぼすこ とが実証されてきたが，その mechanism については， 高血浆渗透圧の影響5)22), 血流再開後の血流の変 化5)2425)26), あるいは虚血時に打ける過度の乳酸産 生4)525)などが考えられるが末だ十分に解明されてい ない. glucose の代りに mannitol を前投与し, 血浆渗透圧 を glucose 投与と同じにしても病理組織学的変化は, 生食水投与の場合と変りなく ${ }^{5)}$, energy metaboliteの 回復の障害は認められるが, glucose 前投与に較べる とその障害の程度が軽いことから, glucose 前投与の 脳虚血に対する悪影響は，一部にはその渗透圧効果に よる ${ }^{22)}$ とても，これのみで全面的にその mechanism を説明出来ないと思われる. Pulsinelli et $\mathrm{al}^{5)}$, Siemk. owicz and Gjedde ${ }^{25}$ ) は血流再開後の脳血流は, 高血糖 のものでは正常血糖のものよりむしろ多いか, 同じで あり，血流再開後の脳血流の状態が，高血糖で脳傷害 が強いといらことに関与している可能性は少ないと主 張している。これに対して, Welsh らは, glucose 前投 与では, 血流再開後に脳血流および energy metabolismの強い障害が起るが, 血流再開後の脳血 流の低下が energy metabolism 障害の原因であるの か結果であるのかは不明であると述べている22124)26). 脳組織中の乳酸の濃度は, 組織の酸素分圧, 血中およ び脳組織中からの解糖のための基質の供給，および静 脈血中への乳酸の流出などによって規定される。高度 の不完全脳虚血あるいは完全脳虚血では，血中からの glucose 执よび酸素の供給はほとんど 0 に近く, 又脳 組織からの乳酸の排出もほとんど無視されるので, 虚 血中の脳組織中の乳酸濃度は虚血開始時の血中グル コース濃度に比例する ${ }^{5}$. 乳酸の産生は $\mathrm{H}^{+}$発生させ るので, 乳酸産生による acidosis が細胞内の $\mathrm{pH}$ homeostasis を乱す，すなわち細胞の生存に必須であ る多くの反応抽び酵素系を障害すると考えられてい る $^{425)}$. しかし, 虚血中の乳酸蓄積は脳組織中で均一で あるのに, 血流再開後の energy metabolite の回復が 一様でないこと ${ }^{22)}$, 脳組織中の乳酸濃度の少しの差が ATPの回復を左右すること到などから, lactic acidosisのみが原因ではないという意見もある22)26).

脳虚血に際しては，遊離脂肪酸，特にアラキドン酸 が増加することは既に報告されて招り ${ }^{6) 321}$ ，著者らの 今回の実験でも，測定したパルミチン酸，ステアリン 酸，オレイン酸，アラキドン酸のすべてで，虚血30分 後には著明な増加がみられ, 特にアラキドン酸の増加 が顕著であった，遊離脂肪酸はそれ自身が，脳浮腫を 誘発したり ${ }^{27)}$, ミトコンドリアの呼吸を抑制し, oxidative phosphorylation の uncoupling るき起す ことが知られている ${ }^{28}$. 血流再開により酸素が再供給 されると,アラキドン酸の酸化により, free radical, プロスタグランジン扰よびトロンボキサンが産生され 
る7).プロスタグランジンおよびトロンボキサンは血 管活性を有することが知られており ${ }^{29)}$ ，血流再開後の 脳血流に影響を及ぼし, 又不飽和脂肪酸の過酸化によ る遊離基反応は生体膜およびミトコンドリアの機能に 対して不可逆的影響を及ぼすと考えられている30). 正 常血糖で15分間の脳虚血で乳酸值が $20 \mathrm{mmoles} / \mathrm{kg}$ の 際の細胞内 $\mathrm{pH}$ は6.5である ${ }^{1)}$. 高血糖に際しては乳酸 値は30mmoles $/ \mathrm{kg}$ 以上に増加しているので4), 細胞内 $\mathrm{pH}$ は6.0あるいはそれ以下の酸性に傾いていると思 われる23)31). 脳虚血に打いては多不飽和脂肪酸が増加 することから, phospholipase $\mathrm{A}_{2}$ が主として活性化さ れる ${ }^{32)}$. phospholipase $\mathrm{A}_{2}$ 活性の至適 $\mathrm{pH}$ は5.5である ので8), 高血糖で lactic acidosis の程度が強ければ, phospholipase $\mathrm{A}_{2}$ 活性が亢進し, 遊離脂肪酸が増加す ると想像されたが, 各 group 間の遊離脂肪酸の増加に 有意差はみられなかったので，高血糖によるより強い lactic acidosisにより, リン脂質の加水分解が促進さ れ, 遊離脂肪酸の蓄積が増加し, これが高血糖群での 血流再開後の機能回復の悪化をもたらすことは実証さ れなからた。

mechanism は未だ十分に解明されていないが, 高度 の不完全脳虚血あるいは完全脳虚血では，虚血開始時 の高血糖が血流再開後の脳機能, 脳代謝および脳の病 理組織学的変化に対して悪影響を及ぼすことは異論が ない。どの程度以上に血糖值が上昇したならば，血流 再開後の脳障害に影響が出るかといら閾值に関して は, 著者らのデータからは $316 \mathrm{mg} / \mathrm{d} l$ 以上では, 脳波の 回復が障害されている。

Welsh et $\mathrm{al}^{26)}$ は $225 \mathrm{mg} / \mathrm{d} l$ 以上の血中グルコース濃 度ではATPの回復が著明に障害されると述べ, Pulsinelli et $\mathrm{al}^{5}$ )の実験では虚血前の血中グルコース濃度 が約 $280 \mathrm{mg} / \mathrm{d} l$ で, 血流再開 24 時間後の虚血性脳組織 傷害が著明に増悪することが観察されている。このよ らに正常の $2-3$ 倍の血中グルコース值の上昇で脳虚 血後の脳機能, 脳代謝の回復が障害され, 脳組織傷害 が増悪するといらことは，糖㽷病の患者では，脳虚血 に陥った際に, 非糖尿病の患者よりも, 神経学的結果 が悪いという報告 ${ }^{33)}$ とく一致している.

\section{文献}

1) Mabe $\mathrm{H}$, Blomqvist $P$, Siesjö $B K$ : Intracellular $\mathrm{pH}$ in the brain following transient ischemia. J Cereb Blood Flow Metabol 3: 109 -114, 1983
2) Friede RL, van Houten WH: Relations between post mortem alterations and glycolytic metabolism in the brain. Exp Neurol 4: 197 $-204,1961$

3) Swanson PD: Acidosis and some metabolic properties of isolated cerebral tissues. Arch Neurol 20:653-663, 1969

4) Rehncrona S, Rosén I, Siesjö BK : Brain lactic acidosis and ischemic cell damage: 1. Biochemistry and neurophysiology. J Cereb Blood Flow Metabol 1 : 297-311, 1981

5) Pulsinelli WA, Waldman S, Rawlinson D, et al : Moderate hyperglycemia augments ischemic brain damage: A neuropathologic study in the rat. Neurology 32 : 1239-1246, 1982

6) Bazán NG: Effects of ischemia and electroconvulsive shock on free fatty acid pool in the brain. Biochim Biophys Acta $218: 1-10$, 1970

7) Wieloch T, Siesjö BK : Ischemic brain injury : The importance of calcium, lipolytic activities, and free fatty acids. Pathol Biol $30: 269-277$, 1982

8) Cooper MF, Webster GR: The differentiation of phospholipase $A_{1}$ and $A_{2}$ in rat and human nervous tissues. J Neurochem 17 : 1543-1554, 1970

9) Pontén U, Ratcheson RA, Salford LG, et al : Optimal freezing conditions for cerebral metabolites in rats. J Neurochem 21: 1127 $-1138,1973$

10) Ljunggren B, Schutz H, Siesjö BK: Changes in energy state and acid-base parameters of the rat brain during complete compression ischemia. Brain Res 73 : 277-289, 1974

11) Siemkowicz E, Hansen AJ: Clinical restitution following cerebral ischemia in hypo-, normo-, and hyperglycemic rats. Acta Neurol Scand 58: 1-8, 1978

12) Kogure K, Busto $R$, Scheinberg $P$, et al : Energy metabolites and water content in rat brain during the early stage of development of cerebral infarction. Brain 97 : 103-114, 1974

13) Nordström C-H, Siesjö BK : Effects of phenobarbital in cerebral ischemia. Part one: Cerebral energy metabolism during pronounced 
incomplete ischemia. Stroke 9 : 327-335, 1978

14) Levine $S$ : Anoxic-ischemic encephalopathy in rats. Am J Pathol 36 : 1-17, 1960

15) Tamura A, Graham DI, McCulloch J, et al : Focal cerebral ischemia in the rat: 1 . Description of technique and early neuropathological consequences following middle cerebral artery occlusion. J Cereb Blood Flow Metabol 1: 53 $-60,1981$

16) Levine S, Sohn D: Cerebral ischemia in infant and adult gerbils. Arch Pathol 87 : 315-317, 1969

17) Pulsinelli WA, Brierley JB: A new model of bilateral hemispheric ischemia in the unanesthetized rat. Stroke $10: 267-272,1979$

18）間部英雄, 梅村 訓, 吉田 毅ら：実験的脳虚血に 打ける局所脳血流量と脳波の関連. 脳神経 34 ： 585-589, 1982

19）鈴木英弘, 木村俊子, 渡辺雅晴ら：体外循環中の脳 波変化. 臨床脳波 $21: 1-9,1979$

20) Myers RE, Yamaguchi S: Nervous system effects of cardiac arrest in monkeys. Arch Neurol 34 : 65-74, 1977

21) Kalimo H, Rehncrona S, Söderfeldt $B$, et al : Brain lactic acidosis and ischemic cell damage : 2. Histopathology. J Cereb Blood Flow Metabol $1: 313-327,1981$

22) Welsh FA, Ginsberg MD, Rieder W, et al : Deleterious effect of glucose pretreatment on recovery from diffuse cerebral ischemia in the cat. II. Regional metabolic levels. Stroke 11: $355-363,1980$

23) Siemkowicz E, Hansen AJ : Brain extracellular ion composition and EEG activity following 10 minutes ischemia in normo- and hyperglycemic rats. Stroke 12:236-240, 1981

24) Ginsberg MD, Welsh FA, Budd WW : Deleterious effect of glucose pretreatment on recovery from diffuse cerebral ischemia in the cat. I.
Local cerebral blood flow and glucose utilization. Stroke 11 : 347-354, 1980

25) Siemkowicz E, Gjedde A : Post-ischemic coma in rat: Effect of different pre-ischemic blood glucose levels on cerebral metabolic recovery after ischemia. Acta Physiol Scand 110: 225 $-232,1980$

26) Welsh FA, Sims RE, McKee AE: Effect of glucose on recovery of energy metabolism following hypoxia-oligemia in mouse brain : Dosedependence and carbohydrate specificity. J Cereb Blood Flow Metabol 3: 486-492, 1983

27) Chan PH, Fishman RA : Brain edema : Induction in cortical slices by polyunsaturated fatty acids. Science $201: 358-360,1978$

28) Wojtczak L: Effect of long-chain fatty acids and acyl-CoA on mitochodrial permeability, transport, and energy-coupling processes. J Bioenerg Biomembr 8: 293-311, 1976

29) Wolfe LS: Eicosanoids: Prostaglandins, thromboxanes, leukotrienes, and other derivatives of carbon-20 unsaturated fatty acids. J Neurochem 38:1-14, 1980

30) Demopoulos HB, Flamm ES, Pietronigro DD, et al: The free radical pathology and the microcirculation in the major central nervous system disease. Acta Physiol Scand Suppl 492 : $91-119,1980$

31) Siesjö BK: Brain energy metabolism. John Wiley, New York, 1978

32) Bazán NG: Free arachidonic acid and other lipids in the nervous system during early ischemia and after electroshock. Adv Exp Med Biol 72 : 317-335, 1976

33) Pulsinelli W, Waldman S, Sigsbee B, et al: Experimental hyperglycemia and diabetes mellitus worsen stroke outcome. Trans Am Neurol Assoc $105: 21-24,1980$ 


\title{
Abstract \\ Influence of blood glucose level on postischemic recovery of the brain function and energy metabolism, and on ischemic neuronal change
}

\author{
Hideo Mabe, M.D., Satoshi Umemura, M.D., Takeshi Yoshida, M.D. and \\ Hajime Nagai, M.D. \\ Department of Neurosurgery, Nagoya City University Medical School
}

Lactate accumulates in the brain tissue during ischemia due to anaerobic glycolysis and produces lactic acidosis. It is suggested that lactic acidosis is an important causative factor for ischemic cell damage. In complete or severe incomplete cerebral ischemia, concentrations of cerebral tissue lactate are influenced by levels of blood glucose.

This study explores the influence of levels of blood glucose in the cerebral ischemic rats on postischemic recovery of the tissue energy metabolism and EEG, on the neuropathology, and on the accumulation of free fatty acids in brain tissue during ischemia.

Severe incomplete cerebral ischemia was induced by four-vessel occlusion and reducing the systolic arterial pressure to $100 \mathrm{mmHg}$ and recirculation was started by release of bilateral carotid artery clamping and restoration of arterial blood pressue to preischemic level. The EEG was continuously recorded from gold-coated screws inserted bilaterally in the parietal bones with the tips in extradural position, against a reference inserted prefrontal bone. The brains were frozen in situ with liquid nitrogen and then chiselled out during irrigation with liquid nitrogen.

Concentrations of ATP and free fatty acids in brain tissue were determined with high performance liquid chromatography. Immediately after the end of 120 minutes of recirculation period, the brains were removed and fixed in formalin and stained by hematoxylin-eosin and luxol fast blue methods to observe ischemic changes.

Experimental animals were divided into 3 groups according to their preischemic blood glucose levels as follows. Group 1 animals were normoglycemic controls (blood glucose levels $116-196 \mathrm{mg} / \mathrm{dl}$, mean $149 \mathrm{mg} / \mathrm{dl}$ ). Group 2 animals were injected $0.5 \mathrm{ml}$ of $50 \%$ glucose solution before ischemia (blood glucose levels $316-430 \mathrm{mg} / \mathrm{dl}$, mean $373 \mathrm{mg} / \mathrm{dl}$ ). Group 3 animals were injected $2 \mathrm{ml}$ of $50 \%$ glucose solution before ischemia (blood glucose levels $684-$ $954 \mathrm{mg} / \mathrm{dl}$, mean $788 \mathrm{mg} / \mathrm{dl}$ ).

After four-vessel occlusion associated with mild hypotension, the EEG became isolectric within 10-20 seconds in all experimental animals. Following 30 minutes of ischemia, a spontaneous EEG returned after 17-35 minutes of recirculation in group 1 animals and after 40-63 minutes in group 2 animals. At the end of the 120 minutes recirculation periods, the EEG activity in group 1 animals showed better recovery than in group 2 . Group 3 animals did not recover any significant EEG activity or showed only a burst suppression pattern.

At 120 minutes of recirculation, concentrations of ATP in the brain were $2.195 \pm 0.062 \mu \mathrm{mol} / \mathrm{g}$ in group 1 animals, $1.877 \pm 0.016 \mu \mathrm{mol} / \mathrm{g}$ in group 2 and $1.501 \pm 0.080 \mu \mathrm{mol} / \mathrm{g}$ in group 3. Ischemic neuronal change, such as shrinkage and dark staining of the cytoplasm and perineuronal edema, was more remarkable in hyperglycemic animals than in normoglycemic animals.

The results demonstrated that hyperglycemia before severe incomplete cerebral ischemia had a deleterious effect on postischemic recovery of EEG activity and brain energy metabolism and markedly augmented morphologic brain damage.

Possible mechanisms by which hyperglycemia before ischemia took a deleterious effect on postischemic recovery were discussed.

(Jpn. J. Stroke 7: 336-343, 1985) 